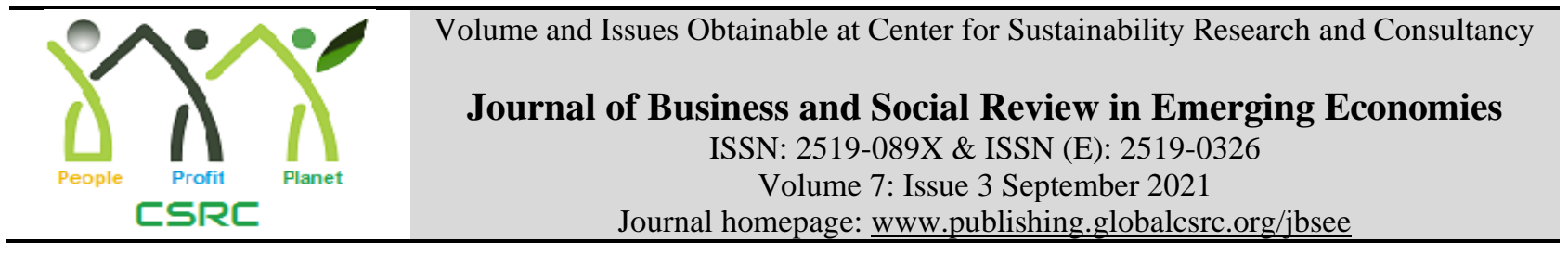

\title{
Innovation and Employee Performance: Mediating Role of Psychological Well Being
}

Adnan Hanif, Department of Public Administration, Faculty of Management Sciences, University of Kotli Azad Jammu \& Kashmir, Pakistan

*Iftikhar Hussain, Department of Public Administration, Faculty of Management Sciences, University of Kotli Azad Jammu \& Kashmir, Pakistan

Filza Hameed, Department of Business Administration, Faculty of Management Sciences, University of Kotli Azad Jammu \& Kashmir, Pakistan

*Corresponding author's email: iftikhar_raja@live.com

\begin{tabular}{l}
\hline ARTICLE DETAILS \\
\hline History \\
Revised format: Aug 2021 \\
Available Online: Sep 2021
\end{tabular}

\section{Keywords}

Organizational Innovation, Psychological Well-being, Employee Performance, Social Exchange Theory.

\section{Jel Classification}

M1, M12

\begin{abstract}
Purpose: Today, the organizational innovation is considered as the most important factor to experience the increased productivity in organizations. Many previous studies focused on the innovation and its' effectiveness for performance at different organizational levels. This study mainly focused on the relationship between organizational innovation and the employee performance. Organizational innovation comprises both creation of new and innovative ideas as well as their successful implementation. Another purpose of this study was to empirical test the mediating role of employee psychological wellbeing in the relationship of organizational innovation and employee performance.
\end{abstract}

Design/Methodology/Approach: The convenient sampling methodology was used to collect the data. The researchers collected the data from 700 employees and their immediate supervisors. The data was collected using a self-administered questionnaire.

Findings: The findings revealed that innovation has an impact on workers performance and their psychological well-being mediates the connection between the organizational innovation and performance of employees.

Implications/Originality/Value: The proposed model was tested and validated through the empirical data, which is an important contribution of current study. These study findings are helpful for academicians, managers, and entrepreneurs.

(C) 2021 The authors, under a Creative Commons AttributionNonCommercial 4.0

Recommended citation: Hanif A., Hussain, I. and Hameed, F. (2021). Innovation and Employee Performance: Mediating Role of Psychological Well Being. Journal of Business and Social Review in Emerging Economies, 7 (3), 699-710. 


\section{Introduction}

The previous researchers mainly focused on the impacts of innovation in the creation of jobs and its disadvantages. The present firm-level analysis presents that how the innovations in job creation led to its destruction, specifically in the short run, but it is often remunerated by the rise in employment growth from service and product innovation. This innovation-promptness in jobs uncertainty may be met with some apprehension by the occupant workers, possibly ending up in anxiety and distress. Furthermore, a few innovations in work activities come up from the beginning of novel work methods and the processes are connected deeply with the preparation of advanced technologies can have both positive or negative impacts on workers' welfare which somehow depends on whether they are a source of labor intensification or job enriching. Henceforth, it can be uttered that innovation can either have negative or positive aftereffects on workers' comfort and well-being. An employee's well-being can be unfavorably affected where, managerial innovations are to workers' damage or impairment (or considered it as such), where the uncertainty is generated by them that is attached with future loss and are introduced as being unfair.

On the other hand, all innovations cannot be perceived likewise by the labor force because some of them are more likely to improve their work arrangements and work conditions than others. For instance, the altered working hours can have a direct consequence on the workers. The innovative working practices (IWPs) is the term coined to refer to those innovations in working conditions and the researchers have focused on these conditions and are keenly considered the activities that are also sometimes explained as 'new', 'high performance', 'high commitment'.

There are two diverse points of view in general, and it says whether IWPs are to be described as workers' well-being. The former comments that IWPs offer the workers the chance to progress the quality of their work-life, through improving the power of decision-making and their personal choices of being responsible. Since, it is seen that at their workplace, the employees are often in search of higher decision-making power and seek more input signals into managerial power of taking decisions (Rogers, 2004), this becomes even more sensible to suppose IWPs as increasing the well-being and job satisfaction in the workers. According to social psychologists, social assistance can make people work on their high demands under the conditions of less power and control (Payne, 1979), wherein the case of employees attending some of the managerial innovations at their workplace. Buhlungu et al. (2008) urge for the fact that trade unions can be considered as the main source of social welfare which, under the theoretical model of Theorell et al. (1990) helps to lessen the effects of work pressure on worker's physical as well as psychological well-being. Nevertheless, the empirical analysis comments on union membership that is not correlated with job satisfaction or well-being. The unions in the commercial enterprise sector in America, the presence of innovative practices, are largely connected with higher labor productivity and the higher rate of innovation (Black \& Lynch, 2004).

According to Keyes et al. (2000), well-being defines as employees' conceptualization and judgment of the quality of their lives along with the quality of their social and psychological functioning. As the well-being of employees enhances, the profitability and the productivity of the organization also enhance. On the other hand, while the well-being of the workers decreases, the stress level will rise even higher and the chances of coping with the stressors and the unsuitable conditions effectively will decrease (Cox et al., 2017). Psychologically peaceful and healthy employees enjoy warm and healthy relationships, feel that they have a resolution of their existence and living, they are developing and progressing as individuals, feel that they can build up their personal space around them that best suits their needs, and feel capable to control their actions to live a standard living. Employees who are having high well-being conditions around are more likely to be independent in making the decision, possess better interpersonal and interactional behaviors, and obtain higher performance ratings altogether (Wright et al., 2004). Current research is designed to address the literature gaps both theoretical and contextual. 
Although organizational innovation is found in the interest of different researchers (Lin et al., 2020; Phan, 2019; Waheed et al., 2019; Wang \& Chen, 2020; Zhou et al., 2019). Although the mentioned researchers have devoted their efforts to analyzing the impacts of using innovation strategies at the organizational level and on firm performance in different countries for various types of firms. After studying the published literature researcher found some gaps. To fill the theoretical and contextual gaps researcher will determine the impact of organizational innovation on workers' execution with the mediation of cognitive or psychological well-being among organizational innovation and the performance of workers. The research was designed to attain the following objectives; to determine the effect of organizational innovation on employee performance and to determine the mediating effect of relationship employee wellbeing among organizational innovation and employee performance.

\section{Literature Analysis \\ Organizational Innovation and Employee Performance}

Business organizations must take the development of human capital into their consideration. Awan and Khalid (2015) discussed that a few companies that gain the competitive edge over their fellow competitors in the business market will have to uphold it via innovations. Awan and Khan (2015) while examining the part of the branch managers to be played in further promotion of innovative practices in commercial banking, come up to a final note that only those who can enhance the earning of their respective organizations who are aware of the value of innovations and attract their customers through applying the innovative techniques and methods.

The multi-faceted indicators of organizational innovation are highlighted today (Chuang et al., 2010; Gilbert Jr \& Reid, 2009; Vigoda-Gadot et al., 2005). Earlier studies discussed diverse management factors that assist organizational innovation (Bate, 2010; Martins \& Terblanche, 2003; Naranjo-Valencia et al., 2011; Wong \& Chin, 2007). This presents the important points that the innovation process must start up with a strategic purpose to render a cognizance of guidance for employees. A close observation to look at the dimensions of innovation discover that they mainly come under three major domains: the preference of a firm's leaders to innovate, self-orientation of employees for innovation, and an environment that supports innovation. Henceforth, for the present study, after looking at the related literature closely, these three dimensions are labeled as follows: leadership innovation propensity, environment innovation propensity, and personal innovation propensity to innovate. Thus, the operational definition for organizational innovation says, adoption along with its production, assimilation, and exploitation of a value-added novelty in social and economic spheres; renewal and enlargement of markets, products, and the services, and support of the production of new methods; and organization of new management arrangements. Hence, it is both a systematic procedure and the result (Crossan \& Apaydin, 2010).

In the light of the above-discussed literature, there is evidence that innovation is the only best solution to increase the adaptability of the organization towards the changing environment. Moreover, it is also important that innovation must be introduced in the organization in such a way that employees may tend to absorb such changes, must be aware of the innovation that is introduced. Innovation can lead the organizations to show better performance it is more right to say that innovation can improve productivity at the individual level as well. Thus, innovation is considered the most influential determinant to enhance employee performance. Therefore, in the current research researcher has hypothesized the following statement:

H1: Organizational innovation has a positive significant effect on employee performance.

Organizational Innovation, Psychological Well-being \& Employee Performance

Psychological well-being can simply be termed as possessing positive mental health 
(Darbanhosseiniamirkhiz \& Wan Ismail, 2012; Edwards et al., 2005). Farrington et al. (2017) in his work, talk about PWB as the consciousness of being involved with life's existing or empirical challenges, whereas, Winefield et al. (2012) define the term as an amalgamation of positive and affective states such as working with optimal effectiveness and comfortability in the individual and social groups' lives. Optimal levels of PWB are more likely to be dependent on the outer conditions of an individual, as well as the problems they face internally (Farrington et al., 2017). Psychological well-being has been examined in numerous organizational contexts, which includes employee well-being (Žižek et al., 2015), job satisfaction (Jones et al., 2015), commitment (Kanten \& Yesiltas, 2015), and the relationships between work and family (Grzywacz \& Butler, 2005). It has been observed in various research that PWB is related to the positive outcomes of the performance of the worker or an employee. For example, Wright and Cropanzano (2000) identify that the benefits of PWB also include the expansion in an individuals' cognitive performance and health, which ultimately leads to a contented society. Another strong notion is presented by Ryan and Deci (2001) that PWB is broadly contemplated as something essential for the effective functioning of human minds and attitudes.

PWB again has a constructive impact on a worker's knowledge-seeking attitude (Edmondson, 1999). Afterward, a willing attitude towards learning in a workplace can make the affirmative surroundings for the performance of employees. Employees are delivered the coping schemes to raise in their repercussion to stressful conditions. Also, when employees trust their organization as if it values their work and contributions for the betterment, they tend to deliver a significant amount of vigor to bring improvement in their job performance. Furthermore, the related theory (Westman, 2001), positive and emotional job adventures grow further from one worker to another co-worker, which in result leads towards the betterment of the group co-workers, the organization, and the department. Compared to this situation, a lack of organizational transformations for the psychological wellness of employees causes an environment that must be unproductive and stressed. The less mental well-being occurs in employees, the more it leads them towards the deficiency in physical health as well. Depression and anxiety have been attached to unsatisfied work performance and nonadoptive psychological well-being. In contrast with this, due to deficiency in work, their performance decreases, and organizations experience their financial losses. Present adoptive theory recommends that PWB has an important effect on job performance altogether.

Employees' work-life balance increases the performance of organizations and their other employees mainly as it brings a flexible and supportive work environment that positively impacts their PWB (Powell \& Greenhaus, 2006). The productive and contended worker hypothesis (Diener et al., 2003) proposes that psychologically well workers perform their duties better (Wright et al., 2004). Organizations' capability to eradicate work-life issues makes them able to develop a better work environment with a successful capital of their organizations which heightens their productive performance (Wu et al., 2020).

Thus, any relationship between job performance and employees' work-life balance passes through the cognitional phases accompanying employee well-being. A philosophical concept called AET (Weiss \& Cropanzano, 1996) can also be applied as a good tool for describing the mediating impacts of psychological well-being. Constructive ideas emerge from many external and internal forces, where one of them is termed here as balance in their work experiences. PWB is not an indirect reaction to the individual's affirmative attitudes and emotions. Hence, it can be expressed those positive emotions are rising from an individual's balanced work-life which again enhances his or her PWB which, in turn, boosts that person's job performance. Therefore, it can be said that a significant work-life balance is more likely to increase positive psychological emotions and capital which enhance an employee's job performance via reinforcing her or his PWB. 
The above-mentioned literature is delivering concrete grounds that employee performance and innovation have a strong interconnection, innovation can lead towards creativity and better productivity and can play a part for the organizations as well. The mental health and emotions of employees are also significant features for productivity and creativity. Henceforth, only innovation cannot be considered as a be-all and end-all to attain positive results at individual levels, there is something else too that can accord negatively or positively for employees' performance. Positive emotions result in positive outcomes in employees and negative emotions are more likely to lead towards psychological distress and can cause various other damages mentioned above (Weiss \& Cropanzano, 1996). So, as a result, the main aim of the researcher is to examine the bridging role of organizational innovation amidst PWB and employee performance. Thus, the statement to test is given as under:

$\mathrm{H} 2$ : Psychological well-being mediates the relationship between organizational innovation and employee performance.

The following research model was developed based on literature analysis and hypotheses of the study.

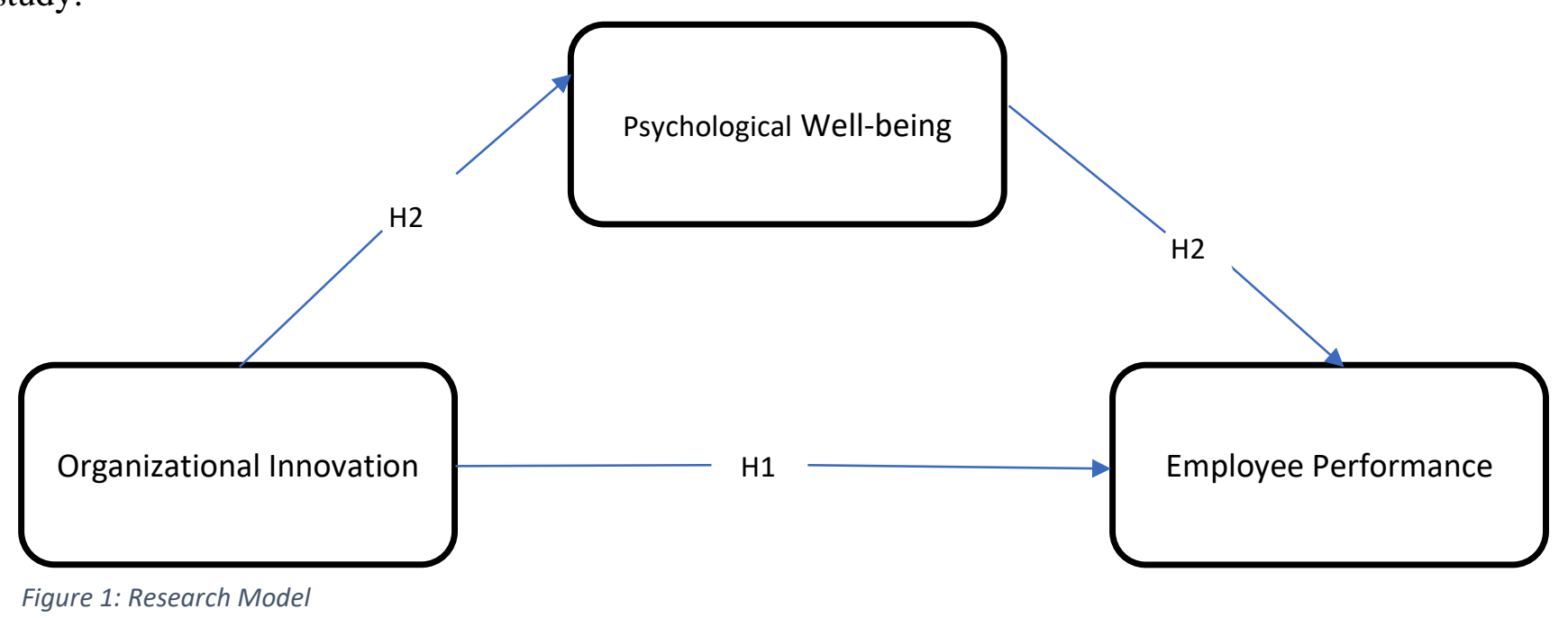

\section{Methodology \\ Research Design}

Research study about any area is sometimes to develop in-depth understandings and to collect further information about it. In literature concerned to academics (Saunders et al., 2015) has defined the term research as a procedure which people attempt systematically to search out things to increase their knowledge. This definition is focusing on two major components one is logic and the other is the obvious and clear purpose of the research. Hence in the current section, the researcher gives the explanation regarding the required approaches, methods and techniques that are necessary for collection of the data and to prove the logics on which the study is based. The aim of the research is to determine the outcomes of organizational innovation for performance of the individuals working in the banking sector of the AJ\&K, Pakistan. Study will also focus to check the mediating role of psychological well-being among Organizational Innovation and employee performance.

\section{Types of Study}

After choosing philosophy the selection of type of study for any research is bit easy task because the type of study is strongly based upon the choice of researcher regarding the philosophy, hence the explanatory (quantitative) is there for current research. To make investigation about the cause and effects among the variables of any research there is need to choose explanatory research (Saunders et al., 2015; Zikmund et al., 2013). For empirical study in current research, it is also based upon explanatory research to determine the impacts of organizational innovation on 
employee performance. Further there is to test the bridging role psychological wellbeing among organizational innovation and employee performance, pacifying role of expected organizational assistance with knowledge sharing is also to be examined.

Setting of Study

In the current research it will be appropriate for data collection that it will be collected with the help of questionnaire. Questionnaires will be distributed among employees and their immediate supervisors. The data will be collected without any biasness and respondents will have enough time based on their convenience for filling, submitting/returning the questionnaire.

Units of Analysis

For different research studies the company, object, group, individual, team, and country can be the unit of analysis (O'leary, 2004; Zikmund et al., 2013). In this research researcher will focus on dyadic approach thus dyads are the unit of analysis in current study.

While collection of data for research studies it is also important factor to consider the time horizon (Saunders et al., 2015). There are two types of time scale for research studies, longitudinal and cross-sectional. The researcher will use time lag data collection in current research, research will have to visit the banks in two stages, once to collect data from employees regarding organizational innovation, perceived organizational support, knowledge sharing, and psychological well-being. In the second phase research will visit banks to collect the data from immediate supervisors of the employees to collect the data for performances of the concerning employees.

\section{Study Population}

Organizational Innovation, in general, refers to the uniqueness in products and services offered by the organizations. Current research is designed to check the impact of innovation on employee performance with the mediating role of psychological well-being. As the focus of the current study is to determine the outcomes of organizational innovation for employees working in the organization and Pakistan the banking sector is one of the sectors that are focusing on innovation now and then, therefore current study will be based upon all the banks that are operating their businesses in Pakistan.

\section{Sampling Method and Sample}

Sampling refers to the selection of representative groups from available large groups in any type of research study (Bell \& Bryman, 2007). It is suggested that despite studying the whole population it is economic and time-saving to take the sample from the whole available population in the research studies (Sinkovics et al., 2005). The current study has been designed for determining the impacts of innovation on employee performance with the mediating role of psychological well-being among Organizational Innovation and Employee Performance. The Banking Sector in the region is the most emerging in the sense of innovation as they are using innovative products and services for customer satisfaction. So, in current research, the targeted sector of the population is the banking sector of AJ\&K, Pakistan. Therefore, all the banks, their branches, and employees working in all the banks are population for current research. As the employees in the banking sector are always busy delivering valued products and services to their customers, they do have not much time to entertain someone for out of routine activity. It is important to consider for the researcher that to avoid any kind of disturbance for employees or customers of the bank while collecting the data from the employees and supervisors/managers. Thus, the researcher will use a convenient sampling technique for the selection of the sample of current research. Convenient sampling will help the researcher to choose those individuals who are easy and conveniently available to the researcher. 


\section{Measures}

The questionnaire for the current study is administered by adopting the scales for selected variables and the details of measures are given below with their references and rating scales. Organizational innovation will be measured by using a developed scale (Hollenstein, 1996; Thomas Hurt \& Ward Teigen, 1977), 6-items scale. The response will be rated from 1 strongly disagree to 5 strongly agree. The psychological well-being will be measured with the help of the GHQ 12-items questionnaire used by Shevlin and Adamson (2005). Responses by respondents will be rated from 1 strongly disagree to 5 strongly agree. Employee performance will be measured through scales developed by the 21-items scale (L. J. Williams \& Anderson, 1991; S. M. Williams, 2001). The response will be rated from 1 strongly disagree to 5 strongly agree.

The Procedure of Collecting the Data

To collect the data of current research, the researcher will approach regional offices of the banks to obtain permissions for data collection from different branches of the banks. The HR department will also have great importance for acquiring the permissions for data collection. Further, after permissions researcher will visit the different branches to meet the branch managers, with the consent of managers researcher will distribute the questionnaires among employees. The questionnaire of the current study has two parts one part consists of the items regarding Organizational Innovation and Psychological Well-Being. The second part of the questionnaire contains the items of Employee Performance. The first part of the questionnaire will be for employees and secondly, the performance of the employees will be obtained from their supervisors/managers from the respective branch of the banks. On the whole, the researcher will have a personal visit to the different branches of the banks in AJ\&K, Pakistan for data collection. To ensure the research ethics researcher will avoid inquiring about personal details from employees and supervisors/managers.

\section{Data Analysis Techniques}

In the current research, the researcher will use the latest version of the analysis of moment structures (AMOS) to perform the different tests on the collected data. A reliability test will be performed to check the reliability of the instrument designed for current research, after acquiring the Cronbach's values for scales correlation will be there for measuring the relationships among variables. Besides, the data analysis includes the exploratory factor analysis also called EFA, Structural Equation Modeling (SEM), the confirmatory factor analysis, and testing the hypothesis. Furthermore, some tests will be there to check the fitness of the research model of current research.

\section{Analysis, Results, and Discussions}

This part of the inquiry mainly consists of the experimental findings, presentation of data, and its analysis to unfold and address the major research questions given in the introduction section, via applying the model termed SEM with the help of AMOS version 24. The CFA model was applied to find the uniqueness of the given variables in the current study and to prove it an errorfree study. Moreover, to measure the connection among correlation and descriptive variables, the mediation and moderation analysis systems were applied.

\section{Descriptive statistics and Correlation Analysis}

In the given below table 1, the statistics for descriptive examination are presented. There, the greater mean value tells the more inclined reactions of the respondents towards the agreement position, whereas, the mean value that is relatively lower, presents the contradiction side of respondents towards the given items of the variable.

Here, the mean value for organizational innovation is mean $=3.69, \mathrm{~S} . \mathrm{D}=0.96$, the psychological well-being shows mean=3.66, S.D $=0.95$, and the mean value of the performance of the 
employee presents the mean=3.55, S.D $=0.99$. These findings unfold that the responses of the respondents are more inclined towards the agreement position.

Table 1: Descriptive Statistics

\begin{tabular}{lllll}
\hline Variables & Minimum & Maximum & Mean & S.D \\
\hline Organizational Innovation & 1.00 & 5.00 & 3.6894 & .96412 \\
Psychological Well-being & 1.17 & 4.92 & 3.6558 & .95271 \\
Performance & 1.00 & 5.00 & 3.5502 & .98725 \\
\hline
\end{tabular}

Correlation analysis of the present investigation is displayed in table- 2 below. Kline (2005) implies that this correlation between the variables should be less than 0.85 for the diverging credibility of the related constructs. The current analysis of the given findings presents the connection among the mentioned variables both negatively and positively. A significant affirmative relationship among the variables is presented as a result. The selected form of correlation analysis tries to provide the grounds for the possible directions for the variables of the current study and their relationship with each other. The findings of the presented examination uncover that till the values of variables are less than 0.85 , they all are more necessarily bear a positive correlation with each other where no negative value can be found as well.

Table 2: The Correlation Analysis

\begin{tabular}{llll}
\hline The Variables & 1 & 2 & 3 \\
\hline 1- Organizational Innovation & 1 & & \\
2- Psychological Well-being & $.326^{* *}$ & 1 & \\
3- Performance & $.241^{* *}$ & $.400^{* *}$ & 1
\end{tabular}

**. Correlation is significant at the 0.01 level (2-tailed).

\section{Addressing the Validity and Reliability Concerns}

Reliability was measured using values of composite reliability (CR). Claes Fornell and David F Larcker (1981) recommended that for data reliability, CR values should be 0.70 or higher. The values of CR for all constructs in the current study are well above the set criteria (see table-3). As mentioned above, the CFA examination was introduced in the study to observe and analyze the validities; discriminant and convergent validness in the study. Bagozzi and Yi (1988) suggested that such validity can be measured with the values of CR, items' standardized factor loading, and the AVE method for average divergence. The CR values that are higher than 0.70, items' standardized factor loading, and AVE values higher than 0.50 , show excellent divergent validity (Bagozzi \& Yi, 1988). The results presented in table 6 and table 7 successfully address the validity concerns (Bagozzi \& Yi, 1988). The discriminant validity can be established through the greater values for the AVE square root than the construct's correlational statistic values and higher AVE values than the maximum share variance (MSV) values. The results are shown in table-3 fulfill the criteria (Claes Fornell \& David F Larcker, 1981).

Table 3: Validity Analysis

\begin{tabular}{lllllllll}
\hline Variables & CR & AVE & MSV & 1 & 2 & 3 & 4 & 5 \\
\hline 1-OI & 0.90 & 0.60 & 0.23 & 0.775 & & & & \\
2- EW & 0.95 & 0.60 & 0.37 & $0.341^{* * *}$ & $0.608^{* * *}$ & $0.386^{* * *}$ & 0.774 & \\
3- EP & 0.96 & 0.55 & 0.24 & $0.291^{* * *}$ & $0.493^{* * *}$ & $0.403^{* * *}$ & $0.384^{* * *}$ & 0.738 \\
\hline
\end{tabular}

Significance of Correlations: $* * * \mathrm{p}<0.001$; Diagonal bold are square root of AVE.

\section{Test of Hypotheses}

After testing the reliability, validity, and measurement model fitness, hypotheses related to the direct and mediating effect were tested applying the Structural equation modeling (SEM), and the findings of direct effect are given in the table of Direct Effect and indirect/mediating effect in table-4. 
Table 4: Direct Effect

\begin{tabular}{llll}
\hline Relationships & Effect & SE & P-value \\
\hline Organizational Innovation $\rightarrow$ Employee Performance & 0.257 & 0.047 & $<.001$ \\
Organizational Innovation $\rightarrow$ Psychological Well-being & 0.378 & 0.057 & $<.001$ \\
Psychological Well-being $\rightarrow$ Employee Performance & 0.440 & 0.062 & $<.001$ \\
\hline
\end{tabular}

\section{Direct Effect}

The findings of interchangeable coefficients for the direct effects and the structural paths that are presented in the above-mentioned table represent the great impact of organizational innovation $(\beta$ $=.257, \mathrm{p}<.001)$ on employee performance. Moreover, there is another great impact of organizational innovation $(\beta=.378, \mathrm{p}<.001)$ on psychological well-being. Furthermore, there is also a significant effect of psychological well-being $(\beta=.440, p<.001)$ and on the performance of employees.

H1: Organizational innovation has a consequential positive effect on workers' performance.

The results shown in table 4, reveal that organizational novelty is greatly and positively connected with the employee's performance (workability) $(\beta=.257, \mathrm{p}<.001)$. Hence, hypothesis $\mathrm{H} 1$ is accepted.

\section{Mediation Effect}

The underlined mediation effect was observed through applying a framework for statistical analysis for mediating impacts (Hayes \& Preacher, 2014). The findings of the mediating effect of stochastic supplies procurement lead-time on operational achievements at the workplace are presented as under:

\begin{tabular}{|c|c|c|c|c|}
\hline Relationship & Effect & SE & LLCI & ULCI \\
\hline $\begin{array}{l}\text { Organizational Innovation } \rightarrow \text { Psychological Well-being } \rightarrow \\
\text { Employee Performance }\end{array}$ & $0.120 * * *$ & 0.021 & 0.082 & 0.163 \\
\hline$($ Direct Effect $=0.127, \mathbf{P}<.001)$ & & & & \\
\hline
\end{tabular}

H2: PWB mediates the connection among the organizational innovation and performance.

The indirect effect values of PWB concerning organizational innovation and the performance of employees lie between $0.082 \sim 0.163(\beta=0.120, \mathrm{P}<.001)$. Henceforth, in the confidence interval of $95 \%$, no zero value is found there. Thus, the conclusion of this can be uttered as the PWB performs the function of intermediary between the organizational innovation and employee performance relationship. Therefore, $\mathrm{H} 2$ is accepted. Moreover, as shown in table-5 the direct effect remains significant in the presence of a mediator, so there is partial mediation. The summary of hypotheses is given below table 6 presents the concise summary of the directed hypotheses.

Table 6: Summary of hypothesis

\begin{tabular}{lll}
\hline Hypothesis & Statement & Results \\
\hline H1 & $\begin{array}{l}\text { Organizational innovation has remarkable positive effects on the performance of an } \\
\text { employee }\end{array}$ & Accepted \\
\hline H2 & $\begin{array}{l}\text { PWB mediates the relationship between organizational innovation and employee } \\
\text { performance. }\end{array}$ & Accepted \\
\hline
\end{tabular}

\section{Conclusions and Recommendations}

The purpose of this article was to produce and display a framework for acknowledging the connection between employee performance and Organizational Innovation and provide insights into how they could be promoted. The other major focus of current research was to examine the mediating function of psychological well-being of employees among organizational innovation 
and employee performance. The findings of this research are providing the fact that organizational innovation helps the organizations to attain a higher level of positive performance from the employees with the mediation of psychological well-being. Employees' positive outcomes are the result of a high level of good mental health, low or no psychological disorders, and positive psychological well-being. Employees in organizations having the focus on innovation now and then feel much better regarding work as compared to the employees of organizations with a low focus on innovation, these all help the organizations to enrich the PWB of employees, and a high level of well-being results in the high level of employee performance. According to the findings of current research, there is a strong positive association between organizational innovation and employee performance, psychological well-being mediates the relationship between organizational innovation and employee performance.

\section{References}

Awan, A. G., \& Khalid, M. I. (2015). Impact of Knowledge Management on organizational performance: A case study of selected Universities in Southern Punjab-Pakistan. Paper presented at the Information and Knowledge Management.

Awan, A. G., \& Khan, A. (2015). Determination of the Role of Branch Managers in Promotion of financial innovation in commercial banks of Pakistan. International Journal of African and Asian Studies, 14, 21-28.

Bagozzi, R. P., \& Yi, Y. (1988). On the evaluation of structural equation models. Journal of the Academy of Marketing Science, 16(1), 74-94.

Bate, J. D. (2010). How to explore for innovation on your organization's strategic frontier. Strategy Leadership.

Bell, E., \& Bryman, A. (2007). The ethics of management research: an exploratory content analysis. British Journal of Management, 18(1), 63-77.

Black, S. E., \& Lynch, L. M. (2004). What's driving the new economy?: The benefits of workplace innovation. The Economic Journal, 114(493), F97-F116.

Buhlungu, S., Brookes, M., \& Wood, G. (2008). Trade unions and democracy in South Africa: union organizational challenges and solidarities in a time of transformation. British Journal of Industrial Relations, 46(3), 439-468.

Chuang, L.-M., Liu, C.-C., Tsai, W.-C., \& Huang, C.-M. (2010). Towards an analytical framework of organizational innovation in the service industry. African Journal of Business Management, 4(5), 790-799.

Cox, T., Kuk, G., \& Leiter, M. P. (2017). Burnout, health, work stress, and organizational healthiness. In Professional burnout (pp. 177-193): Routledge.

Crossan, M. M., \& Apaydin, M. (2010). A multi-dimensional framework of organizational innovation: A systematic review of the literature. Journal of Management studies, 47(6), 1154-1191.

Darbanhosseiniamirkhiz, M., \& Wan Ismail, W. K. (2012). Advanced manufacturing technology adoption in SMEs: An integrative model. Journal of technology management innovation, 7(4), 112-120.

Diener, E., Oishi, S., \& Lucas, R. E. (2003). Personality, culture, and subjective well-being: Emotional and cognitive evaluations of life. Annual review of psychology, 54(1), 403 425.

Edmondson, A. (1999). Psychological safety and learning behavior in work teams. Administrative science quarterly, 44(2), 350-383.

Edwards, T., Delbridge, R., \& Munday, M. (2005). Understanding innovation in small and medium-sized enterprises: a process manifest. Technovation, 25(10), 1119-1127.

Farrington, T., Curran, R., Gori, K., O’Gorman, K. D., \& Queenan, C. J. (2017). Corporate social responsibility: reviewed, rated, revised. International Journal of Contemporary Hospitality Management.

Fornell, C., \& Larcker, D. F. (1981). Evaluating structural equation models with unobservable 
variables and measurement error. Journal of Marketing Research, 18(1), 39-50.

Fornell, C., \& Larcker, D. F. (1981). Structural equation models with unobservable variables and measurement error: Algebra and statistics. In: Sage Publications Sage CA: Los Angeles, CA.

Gilbert Jr, A. H., \& Reid, R. C. (2009). An analysis of the relationships among information scope, organizational proactiveness, and firm performance. Academy of Accounting Financial Studies Journal, 13(4), 1.

Grzywacz, J. G., \& Butler, A. B. (2005). The impact of job characteristics on work-to-family facilitation: testing a theory and distinguishing a construct. Journal of occupational health psychology, 10(2), 97.

Hayes, A. F., \& Preacher, K. J. (2014). Statistical mediation analysis with a multicategorical independent variable. British journal of mathematical statistical psychology

67(3), 451-470.

Hollenstein, H. (1996). A composite indicator of a firm's innovativeness. An empirical analysis based on survey data for Swiss manufacturing. Research Policy, 25(4), 633-645.

Jones, N., Hill, C., \& Henn, C. (2015). Personality and job satisfaction: Their role in work-related psychological well-being. Journal of Psychology in Africa, 25(4), 297-304.

Kanten, P., \& Yesiltas, M. (2015). The effects of positive and negative perfectionism on work engagement, psychological well-being and emotional exhaustion. Procedia economics finance, 23, 1367-1375.

Keyes, C. L. M., Hysom, S. J., \& Lupo, K. L. (2000). The positive organization: Leadership legitimacy, employee well-being, and the bottom line. The Psychologist-Manager Journal, $4(2), 143$.

Kline, T. (2005). Psychological testing: A practical approach to design and evaluation: Sage.

Lin, W., Zhong, W.-J., Su, C.-H., \& Chen, P.-K. (2020). Are Pressuring Employees to Improve Organizational Innovation Still Working? An Empirical Analysis of Manufacturing Companies in China. Sage Open, 10(4), 2158244020963065.

Martins, E.-C., \& Terblanche, F. (2003). Building organisational culture that stimulates creativity and innovation. European Journal of Innovation Management.

Naranjo-Valencia, J. C., Jiménez-Jiménez, D., \& Sanz-Valle, R. (2011). Innovation or imitation? The role of organizational culture. Management decision.

O'leary, Z. (2004). The essential guide to doing research: Sage.

Payne, R. W. (1979). Corporate power and economic policy making in British Columbia, 197275: the case of the mining industry. Simon Fraser University. Theses (Dept. of Political Science),

Phan, T. T. A. (2019). Does organizational innovation always lead to better performance? A study of firms in Vietnam. Journal of Economics Development.

Powell, G. N., \& Greenhaus, J. H. (2006). Is the opposite of positive negative? Untangling the complex relationship between work-family enrichment and conflict. Career development international.

Rogers, M. (2004). Networks, firm size and innovation. Small Business Economics, 22(2), 141153.

Ryan, R. M., \& Deci, E. L. (2001). On happiness and human potentials: A review of research on hedonic and eudaimonic well-being. Annual review of psychology, 52(1), 141-166.

Saunders, M. N., Lewis, P., Thornhill, A., \& Bristow, A. (2015). Understanding research philosophy and approaches to theory development.

Shevlin, M., \& Adamson, G. (2005). Alternative factor models and factorial invariance of the GHQ-12: a large sample analysis using confirmatory factor analysis. Psychological assessment, 17(2), 231.

Sinkovics, R. R., Penz, E., \& Ghauri, P. N. (2005). Analysing textual data in international marketing research. Qualitative Market Research: An International Journal.

Theorell, T., Karasek, R., \& Eneroth, P. (1990). Job strain variations in relation to plasma 
testosterone fluctuations in working men-a longitudinal study. Journal of internal medicine, 227(1), 31-36.

Thomas Hurt, H., \& Ward Teigen, C. (1977). The development of a measure of perceived organizational innovativeness. Annals of the International Communication Association, $1(1), 377-385$.

Vigoda-Gadot, E., Shoham, A., Schwabsky, N., \& Ruvio, A. (2005). Public sector innovation for the managerial and the post-managerial era: Promises and realities in a globalizing public administration. International public management journal, 8(1), 57-81.

Waheed, A., Miao, X., Waheed, S., Ahmad, N., \& Majeed, A. (2019). How new HRM practices, organizational innovation, and innovative climate affect the innovation performance in the IT industry: A moderated-mediation analysis. Sustainability, 11(3), 621.

Wang, F., \& Chen, K. (2020). Do product imitation and innovation require different patterns of organizational innovation? Evidence from Chinese firms. Journal of Business Research, 106, 60-74.

Weiss, H. M., \& Cropanzano, R. (1996). Affective events theory. Research in organizational behavior, 18(1), 1-74.

Westman, M. (2001). Stress and strain crossover. Human relations, 54(6), 717-751.

Williams, L. J., \& Anderson, S. E. (1991). Job satisfaction and organizational commitment as predictors of organizational citizenship and in-role behaviors. Journal of management, 17(3), 601-617.

Williams, S. M. (2001). Is intellectual capital performance and disclosure practices related? Journal of Intellectual capital.

Winefield, H. R., Gill, T. K., Taylor, A. W., \& Pilkington, R. M. (2012). Psychological wellbeing and psychological distress: is it necessary to measure both? Psychology of WellBeing: Theory, Research Practice, 2(1), 1-14.

Wong, S. Y., \& Chin, K. S. (2007). Organizational innovation management: An organizationwide perspective. Industrial Management Data Systems.

Wright, T. A., \& Cropanzano, R. (2000). The role of organizational behavior in occupational health psychology: A view as we approach the millennium. Journal of occupational health psychology, 5(1), 5.

Wright, T. A., Cropanzano, R., \& Meyer, D. G. (2004). State and trait correlates of job performance: A tale of two perspectives. Journal of Business Psychology, 18(3), 365-383.

Wu, H., Li, Y., Hao, Y., Ren, S., \& Zhang, P. (2020). Environmental decentralization, local government competition, and regional green development: Evidence from China. Science of the total environment, 708, 135085.

Zhou, Y., Fan, X., \& Son, J. (2019). How and when matter: Exploring the interaction effects of high-performance work systems, employee participation, and human capital on organizational innovation. Human resource management, 58(3), 253-268.

Zikmund, W. G., Carr, J. C., \& Griffin, M. (2013). Business Research Methods (Book Only): Cengage Learning.

Žižek, S. Š., Treven, S., \& Čančer, V. (2015). Employees in Slovenia and their psychological well-being based on Ryff's model of psychological well-being. Social indicators research, 121(2), 483-502. 